\title{
ANALYSIS OF FACTORS AFFECTING THE PRICE FLUCTUATION OF CAYENNE PEPPER IN MALANG REGENCY
}

\author{
Nurul Laili, Sri Hindarti, and Dwi Susilowati \\ Agribusiness Study Program, Agriculture Faculty, Universitas Islam Malang, \\ Malang 65144, East Java, Indonesia \\ Correspondence Email: nurullaili4@gmail.com
}

Submitted 23 Januari 2020; Accepted 19 November 2020

\begin{abstract}
ABSTRAK
Kabupaten Malang merupakan salah satu daerah dengan kontribusi yang cukup baik dalam pemenuhan cabai rawit di Jawa Timur, namun harga cabai rawit di kabupaten ini sering mengalami fluktuasi yang signifikan. Oleh karena itu penelitian ini dilakukan dengan tujuan 1) Menganalisis pola perubahan harga komoditas cabai rawit di Kabupaten Malang. 2) Menganalisis faktor yang mempengaruhi fluktuasi harga komoditas cabai rawit di Kabupaten Malang. Metode penelitian menggunakan metode kuantitaif dengan data sekunder berupa time series yang diperoleh dari beberapa dinas terkait, yaitu Badan Pusat Statistika Kabupaten Malang, Dinas Perindustrian dan Perdagangan Kabupaten Malang, dan Dinas Ketahanan Pangan, Hortikultura, dan Perkebunan Kabupaten Malang. Analisis data yang digunakan adalah analisis regresi linear berganda dengan variabel tidak bebas adalah harga ditingkat konsumen dari tahun 2009-2018, sedangkan variabel-variabel bebas menggunakan data harga cabai rawit ditingkat produsen, jumlah produksi, dan jumlah konsumsi dari tahun 2009-2018. Hasil penelitian menunjukkan bahwa : 1) Perkembangan harga cabai rawit memiliki trend yang cenderung meningkat selama 10 tahun terakhir. 2) Faktor yang berpengaruh secara nyata terhadap perubahan harga cabai rawit adalah harga di tingkat produsen, sedangkan jumlah produksi cabai rawit dan jumlah permintaan tidak berpengaruh terhadap perubahan harga cabai rawit di Kabupaten Malang.
\end{abstract}

Kata kunci: cabai rawit, fluktuasi, Kabupaten Malang

\begin{abstract}
Malang Regency is one of the regions with a fairly good contribution to fulfilling cayenne pepper in East Java, but the price of cayenne pepper in this district often experience significant fluctuations. Therefore, this research has been conducted with the aim of 1) analyzing the pattern of changes in commodity prices for cayenne pepper in Malang Regency, and 2) analyzing the factors that influence fluctuations in the price of cayenne pepper in Malang Regency. The research method used quantitative method with secondary data, which is time-series data obtained from several relevant agencies, namely the Central Statistics Agency of Malang Regency, the Department of Industry and Trade of Malang Regency, and the Department of Food Security, Horticulture, and Plantation of Malang Regency. Analysis of the data used multiple linear regression analysis with the dependent variable is the price at the consumer level from 2009-2018, while the independent variables are the data of the price of cayenne pepper at the producer level, the amount of production, and the amount of consumption from 2009-2018. The results showed that: 1) the development of the price of cayenne pepper had a trend that tended to increase during the last 10 years, and 2) the factor that significantly influences changes in the price of cayenne peppers is prices at the producer level, while the amount of cayenne production and the number of demands did not affect the price changes of cayenne pepper in Malang Regency.
\end{abstract}

Keywords: cayenne pepper, fluctuation, Malang District 


\section{INTRODUCTION}

Price fluctuation is one of the issues that often occurs in the world of agriculture, especially off-farm. Basically, price fluctuations occur due to an imbalance between the amount of demand and supply in the market. Cayenne pepper is one of the leading national horticultural crops which often experience price fluctuations frequently. This is certainly caused by several factors, one of which is because the amount of supply and demand is often unbalanced, resulting in price instability. According to Rahardja and Prathama (2008), supply can be defined as the amount of a product a producer wants to offer (sell) at various price levels at a particular place and time, while demand is defined as the desire of consumers to buy a good or commodity at a particular place and time when other factors do not experience any changes.

Ningsih (2017) stated that Indonesia has a fairly high level of consumption of cayenne pepper with a total of 1.49 $\mathrm{kg} / \mathrm{capita} /$ year. Meanwhile, according to Muharlis (2007), the supply of chili commodities still depends on the amount of production, while the amount of production in cayenne pepper is mainly determined by its productivity. Furthermore, the 2016 Agricultural Data and Information System Center of the Ministry of Agriculture stated that the development of chili productivity between 1980-2015 in Indonesia tended to fluctuate where this would also affect the price of cayenne pepper. This is also one of the causes of the fluctuation in the price of cayenne pepper in the Malang Regency because this area has a quite good contribution to the fulfillment of chili at the national level. Based on data from Statistics Indonesia of East Java in 2016, Malang Regency is one of the areas that has a reasonably high contribution to chili production in East Java, which is 19.44 $28.76 \%$. Therefore, this study was conducted with the aim of: 1) analyzing the pattern of changes in the price of cayenne pepper in
Malang Regency, and 2) analyzing the factors that influence the price fluctuation of cayenne peppers in Malang Regency.

\section{RESEARCH METHODS}

This study used a quantitative approach in the form of secondary data using time series data for the last 10 years, ranging from 2009 to 2018. The data collected were in the form of data on the amount of production, the amount of consumption, and the price of the cayenne pepper commodity in Malang Regency, both at the producer and consumer levels in the 2009-2018 period. The data were obtained from related offices, including the Food Crops, Horticulture, and Plantation Office of Malang Regency, Industry and Commerce Office of Malang Regency, and Statistics Indonesia of Malang Regency during October-December 2019.

The data analysis in this study used multiple linear regression analysis to explain the effect of factors of price fluctuation of cayenne peppers in Malang Regency, including the price of cayenne pepper at the producer level $\left(\mathrm{X}_{1}\right)$, the amount consumption $\left(\mathrm{X}_{2}\right)$, the amount of production $\left(\mathrm{X}_{3}\right)$ of cayenne peppers. The form of the linear equation is as follows.

$$
\mathrm{Yt}=\mathrm{C}+\beta_{1} \mathrm{X}_{1}+\beta_{2} \mathrm{X}_{2}+\beta_{3} \mathrm{X}_{3}+\mathrm{e}
$$

Information:

$\mathrm{Y} \quad=$ Price fluctuation of cayenne peppers at the consumer level $(\mathrm{Rp} / \mathrm{kg})$

$\mathrm{C}=$ Constant

$\beta_{1} . \beta_{3}=$ Slope

$\mathrm{X}_{1}=$ Price of cayenne pepper at the producer level $(\mathrm{Rp} / \mathrm{kg})$

$\mathrm{X}_{2}=$ The amount consumption (Kg/capita/year)

$\mathrm{X}_{3} \quad=$ The amount of production $(\mathrm{Kg} / \mathrm{year})$

\section{RESULTS AND DISCUSSION}

Fluctuation Patterns of Cayenne Pepper Prices at the Consumer Level in Malang Regency in the 2009-2018 Period 
The price of cayenne pepper at the consumer level continued to fluctuate over the last 10 years from 2009 to 2018. Many factors might be the cause of these price changes. However, fundamentally, price fluctuations occur due to an imbalance between the amount of demand and supply in the market (Sukmawati et al., 2014).

Figure 1 shows a graph of changes in the price of cayenne pepper at the consumer level almost every year. In the annual data presented, it obtained that the lowest price of cayenne pepper at the consumer level was in 2009 with an average price of IDR 13,492/ kg, while the highest price of cayenne pepper was in 2017 with an average price of IDR $50,427 / \mathrm{kg}$.

In line with this explanation, Table 1 presents the price data at the consumer level and the percentage of fluctuation from 2009 to 2018 to determine the rate of increase and decrease.

Based on Table 1, it can be seen that the development of cayenne pepper prices in the Malang Regency from 2009 to 2018 fluctuated every year. The highest increase in the price occurred in 2013 with a percentage of $85.31 \%$ and the highest decrease in the price occurred in 2012 with a percentage of $54.39 \%$.

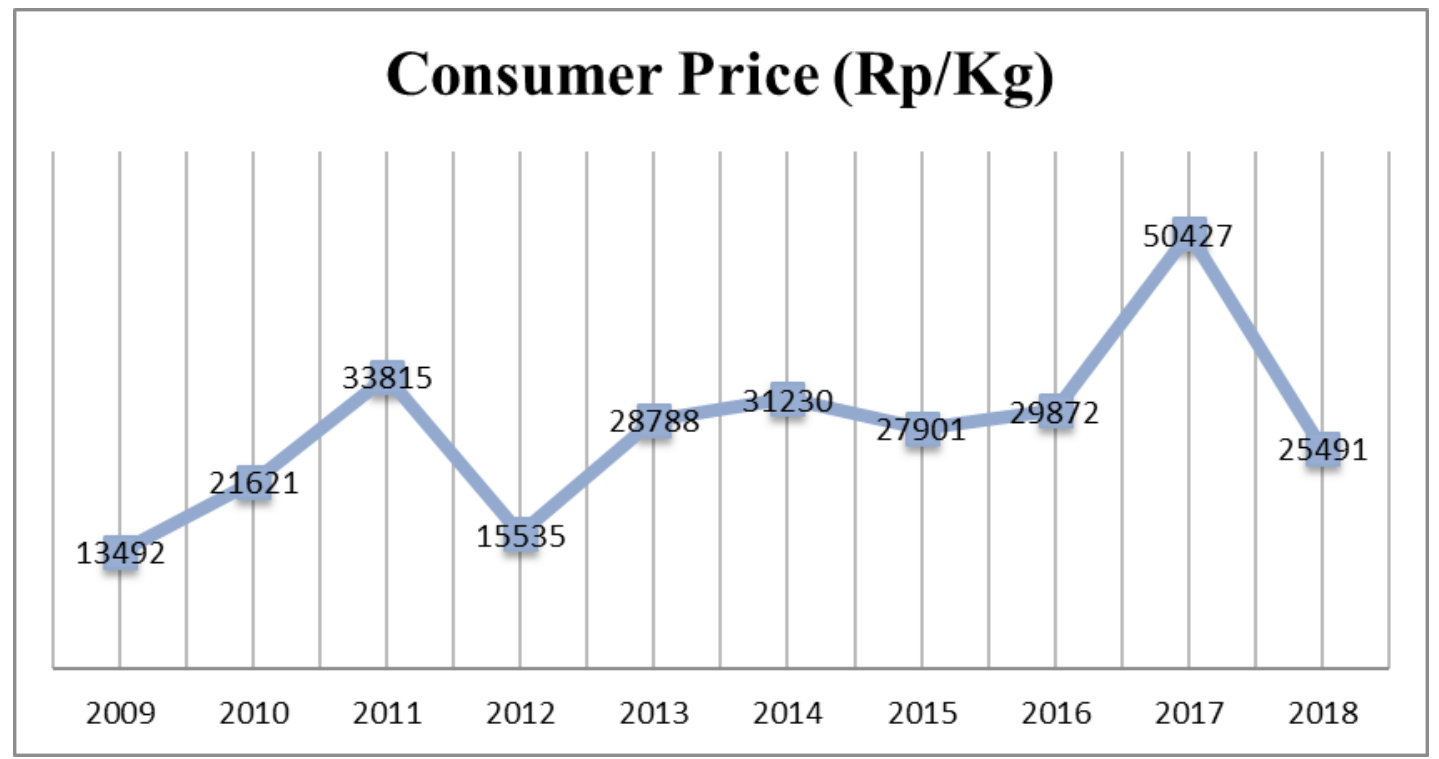

Figure 1. Price of Cayenne Pepper at the Consumer Level in Malang Regency 2009-2018 Source: Department of Industry and Commerce Malang Regency 2009-2018

Table 1. Data Harga Konsumen dan Persentase Fluktuasi Dari Tahun 2009-2018

\begin{tabular}{ccc}
\hline Year & Consumer Price $(\mathrm{Rp} / \mathrm{Kg})$ & Fluctuation Percentage $(\%)$ \\
\hline 2009 & 13.492 & 0 \\
2010 & 21.621 & 60,25 \\
2011 & 33.815 & 56,39 \\
2012 & 15.535 & $-54,05$ \\
2013 & 28.788 & 85,31 \\
2014 & 31.230 & 8,48 \\
2015 & 27.901 & $-10,65$ \\
2016 & 29.872 & 7,06 \\
2017 & 50.427 & 68,81 \\
2018 & 25.491 & $-49,44$ \\
Rata-rata & $27.817,2$ & 17,21 \\
\hline
\end{tabular}

Source: Department of Industry and Commerce Malang Regency 2009-2018 
Based on these data, it was obtained that the average fluctuation of the increase in the price of cayenne pepper at the consumer level in Malang Regency for 10 years from 2009 to 2018 was $17.21 \%$. This may be influenced by several variables to be examined, including the price of cayenne pepper at the producer level, the amount of production, or the amount of consumption.

Similar to the price of cayenne pepper at the consumer level which tended to experience an increasing pattern of change, the three independent variables also had the same pattern, which was a pattern of change that tended to increase every year. It can be seen in Table 2.

The data in Table 2 shows the changes that occurred in the amount of production, prices at the producer level, and the amount of cayenne pepper consumption in the Malang Regency during 2009-2018. The lowest amount of production occurred in 2014 with a total production of $2,536,800$ $\mathrm{kg} /$ year, while the highest amount of production was in 2018 with a total production of $65,631,400 \mathrm{~kg} /$ year with an average fluctuation of the increase of $86.43 \%$. Regarding the price at the producer level, it obtained that the lowest price was in 2009 with a price of IDR 9,217/kg, while the highest price was in 2017 with a price of IDR $36,045 / \mathrm{kg}$ with an average fluctuation of the increase of $5.01 \%$. Regarding the amount of consumption, the lowest value was obtained in 2011 with a consumption value of 0.011 $\mathrm{kg} / \mathrm{capita} /$ year, while the highest value was in 2018 with a consumption value of 0.028 $\mathrm{kg} /$ capita/year with an average fluctuation of the increase of $98.99 \%$.

The changes that occurred in these independent variables may be influenced by other factors that were not analyzed in this study. Principally, the three independent variables are a form of supply and demand for cayenne pepper which can affect the price. Rahardja and Prathama (2008) explained that several factors can affect the supply of a good or commodity, including: the price of the good itself, the price of other related goods, the price of production factors, production costs, production technology, the number of traders or sellers, and government policy.

Table 2. Amount of Production, Prices at the Producer Level, and the Amount of Cayenne Pepper Consumption in the Malang Regency during 2009-2018

\begin{tabular}{ccccccc}
\hline Year & $\begin{array}{c}\text { Amount of } \\
\text { Production } \\
(\mathrm{Kg} / \text { Year })\end{array}$ & $\begin{array}{c}\text { Production } \\
\text { Fluctuation } \\
(\%)\end{array}$ & $\begin{array}{c}\text { Prices at } \\
\text { the } \\
\text { Producer } \\
\text { Level } \\
(\mathrm{Rp} / \mathrm{Kg})\end{array}$ & $\begin{array}{c}\text { Producer } \\
\text { Price } \\
\text { Fluctuation } \\
(\%)\end{array}$ & $\begin{array}{c}\text { Amount of } \\
\text { Consumption } \\
(\text { Kg/Capita/ } \\
\text { Year) }\end{array}$ & $\begin{array}{c}\text { Amount of } \\
\text { Consumption } \\
\text { Fluctuation } \\
(\%)\end{array}$ \\
\hline 2009 & 10.841 .200 & 0 & 9.217 & 0 & 0,0125 & 0 \\
2010 & 9.410 .100 & $-13,2$ & 17.986 & 0 & 0,0127 & 1,60 \\
2011 & 11.249 .100 & 19,54 & 17.986 & 0 & 0,0110 & $-13,38$ \\
2012 & 9.897 .600 & $-12,01$ & 17.986 & 0 & 0,0140 & 27,27 \\
2013 & 9.897 .600 & 0 & 23.125 & 28,57 & 0,0128 & $-8,57$ \\
2014 & 2.536 .800 & $-74,36$ & 23.125 & 0 & 0,0126 & $-1,56$ \\
2015 & 22.315 .800 & 77,96 & 20.815 & $-9,98$ & 0,0280 & 122,22 \\
2016 & 24.372 .000 & 9,21 & 21.526 & 3,41 & 0,0242 & $-13,57$ \\
2017 & 59.974 .500 & 146,07 & 36.045 & 67,44 & 0,0140 & $-42,14$ \\
2018 & 65.631 .400 & 9,43 & 21.848 & $-39,38$ & 0,0178 & 27,14 \\
Average & 22.612 .610 & 86,43 & 20.965 & 5,01 & 0,0159 & 98,99 \\
\hline
\end{tabular}

Source: BPS Malang Regency 2009-2018 
Similar to the supply, an individual's demand for a commodity is also determined by several factors, including: the price of the good itself, the price of other goods that are closely related to that good, household income and the average income of the community, community's tastes, population, forecasts regarding future conditions, income distribution, and the efforts of producers to increase sales. Furthermore, if the demand is the same as the supply based on these factors, a balanced price that can be accepted by producers and consumers will be formed.

Analysis of Factors Affecting the Price Fluctuation of the Cayenne Pepper Commodity in Malang Regency

\section{Normality Test}

Based on Figure 2, it can be seen that the right and left sides have almost a similar shape between the two sides. It is also supported by the Jarque-Bera value of 0.342317 with a probability or $p$-value of 0.842688 . Thus, it can be considered that the p-value of Jarque-Bera was 0.842688 and this value was higher $(>)$ than 0.05 . Based on this explanation, it can be considered that the data in the regression model that were applied between the independent variables and the dependent variable were normally distributed.

\section{Multicollinearity Test}

Based on the analysis, it was found that the price at the producer level, the amount of production, and the amount of consumption had a centered VIF value of less than 10 , in which each was $1.52,1.62$, and 1.071 respectively, so that these variables were declared independent of multicollinearity.

\section{Heteroscedasticity Test}

This analysis obtained results with the probability value of the Chi-Square of 0.6242 $>0.05$. Thus, it can be concluded that the data in this regression model was homoscedastic, or in other words, there was no problem with the assumption of heteroscedasticity.

\section{Autocorrelation Test}

Based on the analysis carried out, the autocorrelation test results showed that the probability value of the Chi-Square Obs*RSquared was 0.2423 , which means that it was higher than $(>)$ 0.05. Thus, it can be stated that this regression analysis did not have problems related to autocorrelation.

\section{Multiple Linear Regression Analysis}

The results of multiple linear regression analysis based on the data on price fluctuations of cayenne pepper and the factors affecting it using the Least Squares Eviews 9.0 method are shown in Table 3.

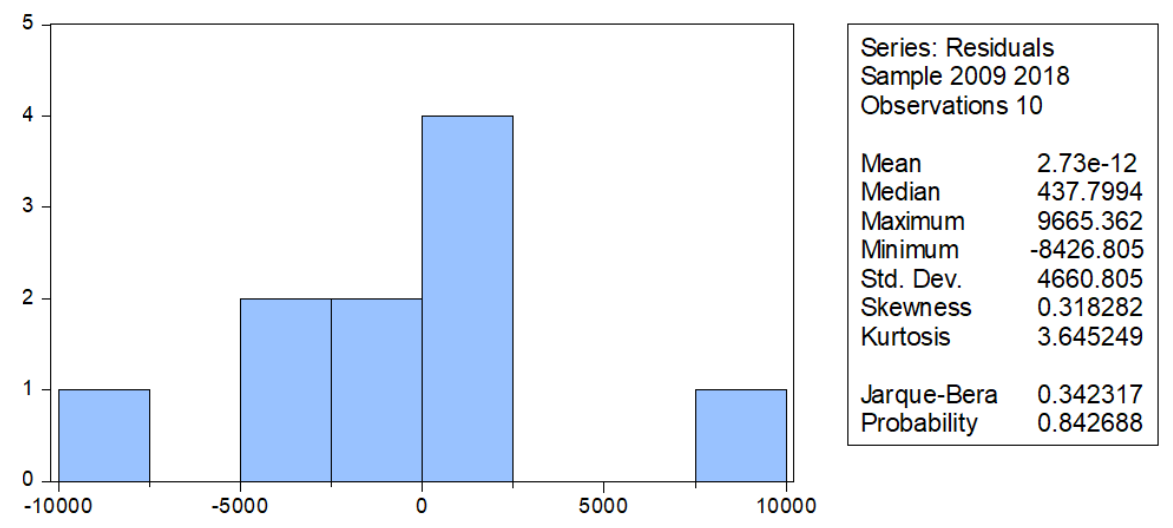

Figure 2. The Result of the Normality Test

Source: Processed Data from BPS Malang Regency, 2019 
Table 3. The Results of Multiple Linear Regression Analysis

\begin{tabular}{lccc}
\hline \multicolumn{1}{c}{ Variable } & $\begin{array}{c}\text { Regression } \\
\text { Coeficient }\end{array}$ & t-Statistic Value & P-value \\
\hline Price at the Producer Level $\left(\mathrm{X}_{1}\right)$ & 1,421088 & 4,037863 & 0,0068 \\
Amount of Consumption $\left(\mathrm{X}_{2}\right)$ & $-71.111,90$ & $-0,205459$ & 0,8440 \\
Amount of Production $\left(\mathrm{X}_{3}\right)$ & $-1,89 \mathrm{E}-05$ & $-0,172517$ & 0,8687 \\
Constant & $-415,5614$ & $-0,048932$ & 0,9626 \\
$\quad$ R-squared $=0,797162$ & & & \\
\hline
\end{tabular}

Source: Processed Data from BPS Malang Regency, 2019

Based on the table of the results of the analysis, the results of the coefficients that can be formed into the formulation of multiple linear regression equations in this analysis were obtained. The equation is as follows.

$$
\begin{gathered}
\mathrm{Y}=-415,5614+ \\
+1,421088 \mathrm{X}_{1}-71.111,90 \mathrm{X}_{2} \\
-1,890 \mathrm{X}_{3}
\end{gathered}
$$

Based on the results of the analysis, it was obtained a constant value of -415.5614 . This means that if each variable (the price of cayenne pepper at the producer level, amount of consumption, and amount of production) is considered to have a constant value or ceteris paribus, the change in the price of cayenne pepper decreases by IDR $415.5614 / \mathrm{kg}$.

The R-squared value was 0.797162 , which means that the price fluctuation of cayenne pepper at the consumer level in the Malang Regency is explained by the existing variables of $79.7162 \%$.

\section{Price of Cayenne Pepper at the Producer Level $\left(\mathbf{X}_{1}\right)$}

The $\mathrm{X}_{1}$ variable or the price of cayenne pepper at the producer level obtained the t-statistic or t-count value of 4.037863 with a p-value of 0.0068 . Thus, this variable had a significant effect on changes in the price of cayenne pepper in the Malang Regency. The coefficient value was 1.421088 with a positive value. Thus, this means that this variable had a positive relationship to changes in the price of cayenne pepper at the consumer level where every IDR $1 / \mathrm{kg}$ price increase of cayenne pepper at the producer level would increase the price of cayenne pepper at the consumer level of IDR $1.421088 / \mathrm{kg}$.

In line with the increase in the price of cayenne pepper at the producer level, it will increase the price of cayenne pepper at the consumer level. This shows a straight comparison between prices at the producer level and prices at the consumer level. Irawan (2016) stated that in the process of price formation, the behavior of farmers and traders has an important role because they can adjust the sales volume according to consumer needs.

\section{Amount of Consumption ( $\left.\mathbf{X}_{2}\right)$}

The amount of consumption of cayenne pepper had a t-value of -0.205459 , and a p-value of 0.8440 . This means that the $\mathrm{X}_{2}$ variable had no effect on changes in the price of cayenne pepper in the Malang Regency.

Demand for these items can also be supported by people's behavior towards the tastes they are interested in. Arfani et al. (2013) stated that consumer behavior can be an important factor that will influence consumer decisions. However, Ariyanti (2017) in her news stated that the demand for chili from the industry reached $40 \%$ and other business players such as hotels, restaurants, and catering reached $30 \%$ of the national needs. This definitely decreases the supply of chilies in the market and makes chilies seem scarce and the price continues to increase. 


\section{Amount of Production $\left(\mathrm{X}_{3}\right)$}

The amount of production variable or $\mathrm{X}_{3}$ obtained a coefficient value of -1.890 with a negative value, while the t-count value was -0.172517 , and the $p$-value was 0.8687 . This shows that the $X_{3}$ variable did not have an effect on price fluctuations of cayenne pepper in the Malang Regency. Stato (2007) stated that an increase in the production of a good at a particular time will result in a decrease in the price of the good. On the other hand, the production that cannot meet demand will increase the price drastically. The amount of production should have an effect on changes in the price of cayenne pepper in Malang Regency, but based on the analysis, it did not occur.

This happened because it was triggered by psychological factors and weather. Purmono (2017) explained that the rainy season causes chili farmers to postpone the delivery of cayenne pepper for fear that the cayenne pepper will rot during the trip. This condition is exploited by speculators by playing with prices in the market. In such cases, farmers do not like the high price of cayenne pepper because their harvest is not fully absorbed by the market. Consequently, many chilies rot and the farmers will certainly suffer losses.

\section{CONCLUSIONS}

The results of the study showed that the cayenne pepper price data plot showed that the price fluctuation of cayenne pepper in Malang Regency during the last 10 years had a tendency to increase every year with an average increase of $17.21 \%$. Based on the results of linear regression analysis, it also obtained that the factor that significantly affected changes in the price of cayenne pepper was the price at the producer level, while the amount of cayenne pepper production and the amount of demand had no significant effect on changes in the price of cayenne pepper in Malang Regency.

Based on the explanation, it is suggested that the government and related parties can assist in maintaining price stability of cayenne pepper at the farmer level in Malang Regency because it is quite influential and assist in maintaining price stability at the consumer level and providing education to the public or farmers to be able to process or provide added value to the commodity of cayenne pepper so that it does not become a perishable and rotten commodity so that it can be more durable and long-lasting.

\section{REFERENCES}

Arfani, A., Salmiah and M. Jufri. 2013. Faktor-faktor yang mempengaruhi sikap konsumen dalam mengkonsumsi cabai merah (Studi kasus: Pasar Brayan, Pasar Denai, Pasar Petisah, Pasar Marelan di Kota Medan). Departemen Agribisnis, Fakultas Pertanian, Universitas Sumatera Utara.

Ariyanti, F. 2017. Industri borong cabai bikin harga meroket. http://m.liputan6.com/bisnis/read/296 1581/industri-borong-cabai-bikinharga-meroket. Aceessed on 14 Januari 2020.

Badan Pusat Statistika. 2016. Provinsi Jawa Timur Dalam Angka 2016. https://jatim.bps.go.id/publication/201 6/07. Aceessed on 14 Januari 2020.

Irawan, B. 2016. Fluktuasi harga, transmisi harga, dan marjin pemasaran sayuran dan buah. Analisis Kebijakan Pertanian 5(4): 358-373.

Muharlis, A. 2007. Peramalan dan Faktorfaktor penentu fluktuasi harga cabai merah di enam kota besar di JawaBali: Kasus pengendalian harga cabai merah pada bagian analisis harga, Badan Ketahanan Pangan Nasional, Deptan RI. 210. Skripsi. Program Sarjana Ekstensi Manajemen Agribisnis, Institut Pertanian Bogor. Bogor. 
Ningsih, A. 2017. Pengantar bisnis budidaya tanaman cabai rawit. Fakultas Pertanian, Universitas Merdeka Surabaya.

Purmono, A. 2017. Panen raya, harga cabai rawit di malang tetap mahal. http://www.google.com/amp/s/nasional .tempo.co/amp/835736/panen-rayaharga-cabai-rawit-di-malang-tetapmahal. Aceessed on 14 Januari 2020.

Pusat Data dan Sistem Informasi Pertanian, Sekretariat Jenderal Kementerian Pertanian. 2016. Outlook komoditas pertanian subsektor hortikultura cabai merah 2016. Jakarta.

Rahardja and Prathama. 2008. Pengantar Ilmu Ekonomi (Mikroekonomi \& Makroekonomi) Edisi Ketiga. Jakarta. Lembaga Penerbit Fakultas Ekonomi Universita Indonesia.

Stato, H. 2007. Analisis faktor-faktor yang mempengaruhi fluktuasi harga bawang merah dan peramalannya (Studi kasus Pasar Induk Kramat Jati, DKI Jakarta). Skripsi. Program Studi Manajemen Agribisnis, Institut Pertanian Bogor. Bogor.

Sukmawati, D., L. Sulistyowati, M. H. Karmana and E. K. Wikarta. 2016. Fluktuasi harga cabai merah keriting (Capsicum annum L) di sentra produksi dan pasar induk (Tinjauan harga cabai merah keriting di Kecamatan Cikajang dan Pasar Induk Kramat Jati Jakarta). Mimbar Agribisnis 1(2): 165-172. 